\title{
Rethinking Democracy: Challenges for global and local governance: Interview with Wil Hout
}

\author{
YAZID ZAHDA
}

In this interview by Yazid Zahda (YZ), Wil Hout (WH), Professor of Governance and International Political Economy at the International Institute of Social Studies (ISS) Erasmus University, the Hague, reflects on challenges that democracy is facing and the need to continuously rethink what democracy is and means, and how this relates to reality. In particular, he argues that democracy, and democratic development, is much more of a local process than we might be willing to acknowledge and that external interventions aimed at promoting democracy need to be aware of this - that ultimately, it is the local and national dynamics and political economy that count much more than external influences.

YZ: The theme of the conference was 'rethinking democracy'. What does rethinking democracy mean to you?

WH: At the conference, I approached the concept of democracy and rethinking democracy from the perspective of political science. Let me quote Jack Lively's Democracy, a little book that was published in 1975 and that I read during one of my first year courses in political science at Erasmus University in the early 1980s. In chapter 2, on the meaning of democracy, Lively says: 'Despite the apparent absence of difficulty, merely to state the simple definition [of democracy as the rule by the people] is to run immediately into a host of definitional ambiguities'. That observation about democracy has informed my thinking on the topic ever since. For me, as I think for most political scientists, democracy is an essentially contested concept.

In the context of democracy, a continuous rethinking has always been and will always be necessary. We always will need to consider what democracy is and whether the concept is still applicable to contemporary reality. The situation of, let's say, the 1970s is incomparable with the situation that we are facing now. Classical notions of democracy may not easily apply to contemporary political realities. There is a second layer to the rethinking of democracy: the assumed linearity that characterizes much of the discourse on democracy needs to be revisited. The path from authoritarianism to democracy isn't linear, as is sometimes suggested in work on political developments. The seminal work of Francis Fukuyama on the end of history and Samuel Huntington on the third wave of democracy, both published at the end of the Cold War, demonstrate this point: both authors pictured democracy as a normative ideal that had been spreading to ever more countries. Now, some 25 years later, a shadow has been cast over the optimism voiced by 
Fukuyama and Huntington to the extent that democratization is no longer seen as a likely trend for many countries.

YZ: Is democracy, in your opinion, the only game in town?

WH: Of course it isn't. The whole point of my presentation during the conference was to cast doubt on the assumed inevitability of the road toward democracy. It is clear that between the classical poles on the spectrum of political systems (authoritarianism and democracy) all kind of new variants have come into being. The rise of competitive authoritarianism, as Levitsky and Way have called it, and the persistence of all kinds of hybrid regimes, somewhere between authoritarianism and democracy, have made clear that democracy is not the only game in town. Also, the deterioration in the functioning of certain so-called consolidated democracies casts doubt on the likelihood of continued democratization. Still, and unfortunately, much of the more policy-oriented literature pretends that democracy is the natural outcome of political evolution.

YZ: How do you then interpret the challenge of global governance institutions, which seem to aspire to domination of the political processes in developing countries, for instance through imposing conditionalities?

WH: I'm rather skeptical about the influence of international institutions on domestic political processes and democratization. In the long run they have relatively little influence because of the dynamics of local political processes and the forces supporting and opposing strengthening democracy. Despite the continuing rhetoric about diminishing national sovereignty, political dynamics remain predominantly national and local. To the extent that international institutions have direct impact, this is not necessarily on the level of democracy, for the very simple fact that many developing countries cannot be considered democracies. In many cases, the inability of countries to withstand the pressure from international institutions is not so much related to democracy, but rather to the limited policy capacity of smaller economies to provide a credible response.

I do agree with Robert Dahl's assessment that it is difficult to achieve democracy in international decision-making. True democracy, understood as popular influence on decision-making in international institutions, will remain a distant ideal. The discussion about notions of a global covenant, brought forward by scholars such as David Held, makes clear that decision-making at the international level is, at best, organized indirectly by state voting: representatives of national governments. At its worst, it is a function of corporate power and private interests. Important economic decisions are predominantly a reflection of corporate interests, with international institutions setting, at most, limits to those decisions by imposing certain regulations.

YZ: To what extent is a valid classification of political regimes - in democratic, hybrid and authoritarian - possible on the basis of quantitative data such as those produced by Freedom House?

WH: Along with many other political scientists interested in the issue of so-called hybrid regimes i.e., regimes that are neither classified as fully democratic nor outright authoritarian, but have characteristics of both - I have been looking for data that make possible a comparison over time. Of the data sets that are available, the Freedom in the World dataset is generally seen as the most comprehensive and complete one. So the decision to use the data produced by Freedom House is pragmatic, but in line with the practice of other political scientists. I have followed here, among others, Morlino's analysis of hybrid regimes, published in the European Political Science Review in 2009. Data on political competition collected by the widely used Polity IV project are generally much less comprehensive.

YZ: You claim that democracy promotion should be reassessed as a result of the persistence of hybrid regimes. Why?

WH: I think that we should not expect too much of external policies such as those aimed at democracy promotion, because the actual nature of decision-making in political systems is determined much more by national and local forces and the domestic political economy, than by outside influences. A sign of this is that the optimism created by the Arab Spring, holding that support of particular oppositional forces would produce democracy, has largely disappeared. 
In a book that Richard Robison and I edited on Governance and the Depoliticisation of Development we argued that external forces wishing to bring about political reform in developing countries often are strange bedfellows with the regimes they wished to change in the first place. Why? Well, because the local regimes play along with the outside forces, pretending that they are reforming, but are actually maintaining the behaviour that they always practiced.

YZ: Isn't democracy promotion then becoming a tool to legitimize intervention by outsiders who have other purposes?
WH: Not necessarily, as there are of course all kinds of actors that are genuinely interested in democratic reforms. The UNDP programme on democratic governance, and some programmes of the so-called like-minded bilateral donors (such as Sweden or The Netherlands), can be seen as examples of such endeavours. Next to this, democracy promotion interventions may be used to legitimize all sorts of other foreign policy decisions and goals. This, however, is nothing new under the sun as we know that traditionally foreign policies have been applying a variety of instruments, some of them disingenuously, to achieve their objectives. 